\title{
BIOCHEMICAL STUDIES ON PTERIDINES IN PLANTS ${ }^{1}$ \\ II. BIOGENESIS OF FOLIC ACID IN GREEN LEAVES : ENZYMATIC SYNTHESIS OF DIHYDROPTEROIC ACID FROM GUANOSINE COMPOUNDS AND MECHANISM OF ITS SYNTHETIC PATHWAY ${ }^{2}$
}

\author{
HISATERU MITSUDA, YUZURU SUZUKI, KENJIRO TADERA \\ AND FUMIO KAWAI ${ }^{3}$ \\ Laboratory of Nutritional Chemistry, Faculty of Agriculture, \\ Kyoto University, Sakyo, Kyoto
}

(Received February 15, 1966)

Reynolds and Brown $(1,2)$ demonstrated the enzymatic net synthesis of the pteridine moiety of dihydrofolic acid from guanosine nucleotides by cell-free extracts of Esherichia coli. Recently, a similar reaction was shown by Shiota and Palumbo (3), using the extracts of Lactobacillus plantarum, and, on the basis of the study of formate production in the reaction involving the removal of carbon 8 of guanine nucleotides, they suggested that GTP or GDP but not GMP is the immediate substrate. Futhermore, a recent communication with the cell-free extracts of Salmonella typhimurium by Dalal and Gots (4) indicated that GTP was the most efficient of the guanine nucleotides tested.

In 1961, Weygand et al. (5) proposed a hypothetical pathway for pteridine biosynthesis from guanosine or GMP on the basis of the observed labelled pattern in the leucopterin isolated from a butterfly Pieris brassicae. The over-all pathway proposed that 4-(5'-phosphoribosyl)amino-2,5-diamino-6-hydroxypyrimidine and a phosphorylated form of 2-amino-4-hydroxy-6-(D-erythro-1', $2^{\prime}, 3^{\prime}$,-trihydroxypropyl)dihydropteridine were intermediary compounds. This pteridine was later isolated by Rembold and Buschmann (6). Jones, Reynolds and Brown (7) represented that the extracts of $E$. coli could convert this pteridine into dihydropteroic acid.

The enzymatic synthesis of dihydropteroic acid or dihydrofolic acid from 2 amino-4-hydroxy-6-hydroxymethyldihydropteridine and $p$-aminobenzoic acid or $p$ aminobenzoylglutamic acid in the presence of ATP and $\mathrm{Mg}^{2+}$ was demonstrated in plants by the present authors $(8,9)$, using the extracts of spinach leaves. Afterwards the same observations were presented by Iwai et al. (10) with soy been seedlings. The authors (11) extended their studies and obtained preliminary evidence that cell-free extracts of Brassica pekinensis Rupr (HAKUSAI) could catalyze the conversion of guanosine compounds into dihydropteroic acid. Together

\footnotetext{
${ }^{1}$ Supported by an aid from Vitamin B Research Committee.

${ }^{2}$ An outline of this paper was presented at 38th annual meeting of the Japan Biochemical Society at Fukuoka (October, 1965).

3 満田久輝，鈴木 譲，田寺謙次郎，河合文雄。
} 
with these findings, the study of the mechanism of the biosynthesis especially on the effectiveness of various synthetic pteridines as the donor for forming dihydropteroic acid are described in this paper.

\section{EXPERIMENTAL}

\section{Materials}

2-Amino-4-hydroxy-6-hydroxymethylpteridine was synthesized according to the method of Forrest and Walker (12), or Waller et al. (13), and monophosphate and pyrophosphate esters of this pteridine were prepared by the procedure of Shiota, Disraely and McCann (14). They were obtained as lead salts and stored in a refrigerator at $20^{\circ}$. When the esters were tested for the enzyme reaction, lead was removed as lead sulfide by bubbling the solution of the ester in cold $0.1 \mathrm{~N}$ $\mathrm{HCl}$ with hydrogen sulfide, follwed by centrifugation (14). 2-Amino-4-hydroxy-6(D-erythro-trihydroxypropyl)-pteridine was obtained from condensation of 2,4,5triamino-6-hydroxypyrimidine sulfate (15) and D-ribose or D-arabinose according to Rembold and Buschman (6). The corresponding L-erythro, D-threo and L-threo isomers were synthesized by the same method by changing the sugar to L-arabinose, D-xylose and L-xylose, respectively. 2-Amino-4-hydroxypteridine was obtained by the procedure of Mowat et al. (16), pteroic acid according to Waller et al. (17). 2-Amino-4-hydroxy-6-(L-arabo-1', $2^{\prime}, 3^{\prime}$-trihydroxy-4'-deoxybutyl)pteridine, 2-amino-4-hydroxy - 6 -(D-arabo- $1^{\prime}, 2^{\prime}, 3^{\prime}, 4^{\prime}$-tetrahydroxybutyl) pteridine and 2-amino-4-hydroxy-6-(Dlyxo-1', $2^{\prime}, 3^{\prime}, 4^{\prime}$-tetrahydroxybutyl)pteridine were prepared by condensation of $2,4,5$ triamino-6-hydroxypyrimidine (15) with L-rhamnose, D-glucose and D-galactose, respectively (18). The pteridines were reduced to the corresponding dihydroform by treatment with sodium hydrosulfite as suggested by Futterman (19), when the pteridines were used in the enzyme reactions.

Crystalline ATP, GTP, guanosine, guanine, DL- $\alpha$-glycerophosphate and tris(hydroxymethyl)aminomethane were purchased from Sigma Chemical Company; adenine, 3-phosphoglycerate from Nutritional Biochemicals Corporation; hypoxanthine from Zellstofffabrik Waldhof; sodium pyruvate, L-arabinose and D-arabinose from E. Merck, A. G., Darmstadt; D-ribose from Wako Pure Chemical Industries Ltd.; D-xylose and highly purified agar from Difco Laboratories; Norit A from Fischer Scientific Company; L-xylose and sodium glyoxylate from Tokyo Chemical Industry Co. Ltd.; Folic Acid Assay Medium "Nisan" for Streptococcus faecalis $R$ (ATCC No. 8043) and yeast extract from Nissui Chemical Industries Ltd.; sodium ascorbate from Takeda Pharmaceutical Industries Ltd., and Sephadex G-50, medium, from Pharmacia, Uppsala. All other chemicals including folic acid, inosine, xanthine, p-aminobenzoic acid, L-rhamnose, D-glucose and D-galactose were of the best quality available.

\section{Preparation of Cell-Free Extracts from Brassica pekinensis Rupr}

In all the preparation and assays of the enzyme, the phosphate used was potassium salt unless otherwise stated. Two hundred grams of leaves of Brassica pekinensis Rupr were homogenized at $4^{\circ}$ with $50 \mathrm{ml}$ of $0.2 \mathrm{M}$ phosphate buffer, $\mathrm{pH} 7.0$, containing $40 \mathrm{mM} \mathrm{Na} \mathrm{Na}_{2} \mathrm{SO}_{3}$. The homogenate was filtered through gauze and centrifuged at $10,000 \mathrm{rpm}$ for one hour at $0^{\circ}$. To the resulting supernatant, 
$150 \mathrm{ml}, p$-aminobenzoic acid was added to give a final concentration of $2 \mathrm{mM}$, and then solid ammonium sulfate was added up to 0.55 saturation, stirring for 30 minutes at $4^{\circ}$. The precipitate was collected by centrifugation at $8,000 \mathrm{rpm}$ for 20 minutes at $0^{\circ}$, dissolved in $0.05 \mathrm{M}$ Tris- $\mathrm{HCl}$ buffer, $\mathrm{pH} 7.0$, containing $0.5 \mathrm{mM}$ p-aminobenzoic acid and $10 \mathrm{mM} \mathrm{Na} \mathrm{Na}_{3}$, and dialyzed against the same buffer, 2 liters for two hours under stirring at $4^{\circ}$. After centrifuging the dialysate at $10,000 \mathrm{rpm}$ for 20 minutes at $0^{\circ}, p$-aminobenzoic acid to make a concentration of $5 \mathrm{mM}$ and Norit A, equivalent in weight to the protein present, were added succesively to the supernatant, stirring for 10 minutes at $4^{\circ}$. The suspension was centrifuged at $10,000 \mathrm{rpm}$ for 20 minutes at $0^{\circ}$ to remove the charcoal. The clear supernatant fluid will be refered to as the "charcoal-treated extract" in this paper (9).

A column of Sephadex G-50, medium, $(2.2 \times 24 \mathrm{~cm})$, jacketed for cooling at $4^{\circ}$, was washed with $150 \mathrm{ml}$ of $0.1 \mathrm{M}$ Tris- $\mathrm{HCl}$ buffer, $\mathrm{pH} 7.65$. Three $\mathrm{ml}$ of the charcoal-treated extract was applied on the top of the column, washed into the gel with $3 \mathrm{ml}$ of the same buffer and developed. Light brown colored protein fractions were collected and used in the following experiments, unless otherwise mentioned.

\section{Microbiological Assay}

Dihydropteroic acid produced was determined by microbiological assay with St. faecalis $R$ as described in the previous report (9). Although only dihydropteroic acid was produced in the enzyme reaction of $p$-aminobenzoic acid with pteridine donors (9), folic acid was used as the standard in the assay for convenience and the values indicated in this paper are expressed as folate equivalents.

\section{Enzyme Assay}

The enzyme reaction was carried out in the Thunberg tubes under nitrogen or hydrogen in an air incubator at $30^{\circ}$. The reaction was stopped by immidiate cooling in an ice bath and adding $0.1 \mathrm{ml}$ of mercaptoethanol. An aliquot of the mixture was used for microbiological assay as indicated before (9). Protein was determined by the method of Kalcker (20), measuring the optical densities at 260 and $280 \mathrm{~m} \mu$.

\section{RESULTS AND DISCUSSION}

\section{Enzymatic Synthesis of Dihydropteroic Acid from Guanosine Compounds}

Various purines were tested for enzymatic formation of dihydropteroic acid. As shown in Table 1, only guanosine and GMP were most effectively utilized in the synthesis. All the other purines were without any effect, although hypoxanthine showed a much lesser activity. The results in Table 2 represent that ATP, $\mathrm{Mg}^{2+}$ and phosphate were all required for the enzymatic transformation from guanosine. Higher concentration of phosphate, $\mathrm{Mg}^{2+}$, ATP and mercaptoethanol were found to result in remarkable inhibition of the synthesis.

2. Comparison of Effectiveness of Guanosine Compounds to Form Dihydropteroic Acid

The preparation of the enzyme for this experiment was as follows: The charcoal-treated extract was dialyzed at $4^{\circ}$ over-night under vigorous stirring against 
TABLE 1

Effectiveness of Purine Compounds as Precursor for Enzymatic Synthesis de novo of Dihydropteroic Acid

Reaction mixtures contained: $p$-aminobenzoic acid, $0.03 \mu$ mole; $\mathrm{MgSO}_{4}, 10 \mu$ moles; sodium phosphate, $20 \mu$ moles, $\mathrm{pH} 8.0$; mercaptoethanol, $30 \mu$ moles; ATP, $2.5 \mu$ moles ; $\mathrm{CuSO}_{4}, 0.001 \mu$ mole; purine derivative, $0.3 \mu$ mole and enzyme protein, $11.7 \mathrm{mg}$ of Brassica pekinensis $\mathrm{Rupr}$ in $2 \mathrm{ml}$ of Tris- $\mathrm{HCl}, 0.1 \mathrm{M}, \mathrm{pH} 7.95$.

Incubated for $4 \mathrm{hr}$ at $30^{\circ}$ under nitrogen. Reaction was stopped by addition of $0.1 \mathrm{ml}$ of mercaptoethanol. Dihydropteroic acid was determined by microbiological assay with $S$. faecalis $R$.

\begin{tabular}{lcc}
\hline & \multicolumn{2}{c}{ Folate equivalents formed } \\
\cline { 2 - 3 } Purine derivative & Observed & $\begin{array}{c}\text { Corrected } \\
\text { against control }\end{array}$ \\
\hline Control $a$ & \multicolumn{2}{c}{ m $\mu g / 4$ hr in $2 m l$} \\
GMP & 107 & 0 \\
Guanosine & 375 & 268 \\
Guanine & 283 & 176 \\
Adenine & 61 & 0 \\
Xanthine & 107 & 0 \\
Hypoxathine & 107 & 49 \\
Adenosine & 156 & - \\
Inosine & 89 & - \\
\hline
\end{tabular}

$a$ Control containing enzyme protein, $\mathrm{CuSO}_{4}$, mercaptoethanol and Tris buffer.

TABLE 2

Enzymatic Synthesis de nowo of Dihydropteroic Acid from Guanosine Derivatives

Reaction mixtures contained : p-aminobenzoic acid, $0.05 \mu$ mole; $\mathrm{MgSO}_{4}, 10 \mu$ moles ; potassium phosphate, $20 \mu$ moles, $\mathrm{pH} 8.0$; mercaptoethanol, $30 \mu$ moles; ATP, $2.5 \mu$ moles; $\mathrm{CuSO}_{4}, 0.001 \mu$ mole; guanosine derivative, $0.3 \mu$ mole and enzyme protein, $12.4 \mathrm{mg}$ of Brassica pekinensis Rupr in $2 \mathrm{ml}$ of Tris- $\mathrm{HCl}, 0.1 \mathrm{M}, \mathrm{pH} 7.95$.

Incubated for $4 \mathrm{hr}$ at $30^{\circ}$ under nitrogen.

\begin{tabular}{lcc}
\hline \hline & \multicolumn{2}{c}{ Folate equivalents formed } \\
\cline { 2 - 3 } Reaction mixture & Observed & $\begin{array}{c}\text { Corrected } \\
\text { against control }\end{array}$ \\
\hline & \multicolumn{2}{c}{$m \mu g / 4 h r i n 2 m l$} \\
Control $a$ & 46 & 0 \\
Complete (guanosine) & 174 & 128 \\
Omit MgSO & 66 & 20 \\
Omit ATP & 72 & - \\
Omit guanosine & 40 & 26 \\
Omit phosphate & 72 & 26 \\
Omit enzyme & 0 & 138 \\
Guanine used & 72 & - \\
GMP used & 184 &
\end{tabular}

${ }^{a}$ Control containing enzyme protein, $\mathrm{CuSO}_{4}$, mercaptoethanol and Tris buffer.

500 volumes of $0.015 \mathrm{M}$ Tris- $\mathrm{HCl}$ buffer, $\mathrm{pH}$ 7.0. After centrifuging the dialysate at $10,000 \mathrm{rpm}$ for 20 minutes at $0^{\circ}$, the supernatant solution was applied on a Sephadex G-50 column $(2.2 \times 24 \mathrm{~cm})$, which had been previously equilibrated with $0.03 M$ Tris- $\mathrm{HCl}$ buffer, $\mathrm{pH}$ 7.65. The column was cooled, and developed with the same buffer. The protein emerging from the column were collected. Using the 
dialyzed enzyme in the reaction, dihydropteroic acid was formed from guanosine compounds as given in Table 3. It can be seen that guanosine nucleotides were the most active, though prolonged dialysis resulted in considerable loss of the enzyme activity. Guanosine, which was active as substrate in the crude extracts, has been removed from the conversion system in the step of this purification.

TABLE 3

Effects of Guanosine Derivatives as Precursors for Enzymatic

Synthesis de novo of Dihydropteroic Acid (One step incubation)

Reaction mixtures contained: $p$-aminobenzoic acid, $0.04 \mu$ mole; $\mathrm{MgSO}_{4}, 5 \mu$ moles; potassium phosphate, $100 \mu$ moles, $\mathrm{pH} 8.0$; mercaptoethanol, $30 \mu$ moles; ATP, $2 \mu$ mole; guanosine derivative, $0.2 \mu$ mole and enzyme protein, $9.3 \mathrm{mg}$ of Brassica pekinensis Rupr in $2 \mathrm{ml}$ of Tris- $\mathrm{HCl}, 0.1 \mathrm{M}, \mathrm{pH} 7.95$.

Incubated for $4 \mathrm{hr}$ at $30^{\circ}$ under nitrogen gas.

\begin{tabular}{cc}
\hline Guanosine derivative & Folate equivalents formed \\
\hline GTP & $m \mu g / 4 \mathrm{hr}$ in $2 \mathrm{ml}$ \\
GDP & 23.3 \\
GMP & 27.9 \\
Guanosine & 26.4 \\
Control $^{a}$ & 0 \\
\hline
\end{tabular}

${ }^{a}$ Control containing enzyme protein, mercaptoethanol, potassium phosphate and Tris buffer.

In order to decide which guanosine nucleotides might be included as the direct precursor in the biosynthesis of dihydropteroic acid, the enzyme system was tried to be splitted into two stages of the reaction. In the first, the reaction system containing guanosine compound and the dialyzed enzyme was incubated at $30^{\circ}$ for 3 hours under nitrogen. At the end of the incubation, the medium was heated at $100^{\circ}$ for 2 minutes, and then centrifuged at 3,000 rpm for 10 minutes to remove the resulting precipitate. After $0.5 \mathrm{ml}$ of the supernatant was added to the second reaction mixture, containing $p$-aminobenzoic acid, $\mathrm{Mg}^{2+}$, ATP and the charcoaltreated extract obtained after gel-filtration with Sephadex G-50, the second reaction was allowed to proceed at $30^{\circ}$ for 3 hours under nitrogen. As indicated in Table 4, GDP was utilized most efficiently as the pteridine donor for the enzymatic production of dihydropteroic acid; about three times more active than GMP and about 1.7 times as effective as GTP. When GTP was used, the conversion into dihydropteroic acid was absolutely dependent on ATP and $\mathrm{Mg}^{2+}$ under the conditions given in Table 4 (see Table 5). These results provided the possibility that the participating guanine congener is GTP or GDP rather than GMP or guanosine; GDP or GTP might be transformed without ATP and $\mathrm{Mg}^{2+}$ during the first reaction period into a pteridine which can couple with $p$-aminobenzoic acid in the presence of ATP and $\mathrm{Mg}^{2+}$ to form dihydropteroic acid.

These findings in the higher plant on the enzymatic conversion of guanosine compounds to dihydropteroic acid were compatible with those obtained by Reynolds and Brown $(1,2)$ with E. coli system, and of Shiota and Palumbo (3) in cellfree extracts of Lactobacillus plantarum. Very recently, Dalal and Gots demonstrated the same observations using Salumonella typhimurium (4). 


\section{TABLE 4}

Effects of Guanosine Derivatives as Precursors for Enzymatic Synthesis de novo of Dihydropteroic Acid (Two step incubation)

1 st incubation: reaction mixtures contained: potassium phosphate, $10 \mu$ moles; $\mathrm{CuSO}_{4}, 1.5 \times 10^{-3} \mu$ mole; mercaptoethanol, $2 \mu$ moles; guanosine derivative, $0.2 \mu$ mole and enzyme protein, $9.0 \mathrm{mg}$ of Brassica pekinensis $R u p r$ in $1 \mathrm{ml}$ of Tris- $\mathrm{HCl}$, $0.02 M, \mathrm{pH} 8.1$.

Incubated for $3 \mathrm{hr}$ at $30^{\circ}$ under nitrogen. Reaction was stopped by heating at $100^{\circ}$ for $2 \mathrm{~min}$ and reaction mixture was centrifuged at $3,000 \mathrm{rpm}$ for $10 \mathrm{~min}$. The supernatant, $0.5 \mathrm{ml}$ was used in the 2 nd reaction.

$2 \mathrm{nd}$ incubation: reaction mixtures contained: $p$-aminobenzoic acid, $0.03 \mu$ mole; potassium phosphate, $100 \mu$ moles; $\mathrm{MgSO}_{4}, 10 \mu$ moles ; ATP, $5 \mu$ moles ; mercaptoethanol, $100 \mu$ moles; the super of 1 st reaction mixture, $0.5 \mathrm{ml}$ and the enzyme protein, $18.2 \mathrm{mg}$ in $2 \mathrm{ml}$ of Tris- $\mathrm{HCl}, 0.09 \mathrm{M}, \mathrm{pH} 8.2$.

Incubated for $3 \mathrm{hr}$ at $30^{\circ}$ under nitrogen. Reaction was stopped by addition of $0.1 \mathrm{ml}$ mercaptoethanol.

\begin{tabular}{cc}
\hline Guanosine derivative & $\begin{array}{c}\text { Folate equivalents formed } \\
\text { in 2ml of the 2nd reaction }\end{array}$ \\
\hline & $m \mu g / 3 \mathrm{hr}$ \\
GTP & 15.5 \\
GDP & 26.3 \\
GMP & 9.3 \\
Guanosine & 3.1 \\
Control &
\end{tabular}

${ }^{a}$ Control containing enzyme protein, $\mathrm{CuSO}_{4}$, mercaptoethanol, potassium phosphate and Tris buffer.

TABLE 5

Cofactor Requirements for Enzymatic Synthesis de novo of Dihy. dropteroic Acid from GTP

The condition used were similar to those described in Table 4.

\begin{tabular}{lc}
\hline Reaction mixture & $\begin{array}{c}\text { Folate equivalents formed } \\
\text { in 2ml of the 2nd reaction }\end{array}$ \\
\hline Control & $m \mu g / 3 \mathrm{hr}$ \\
Complete (GTP) & 0 \\
Omit MgSO & 15.5 \\
Omit ATP & 9.3 \\
Omit GTP & 6.2 \\
Omit enzyme & 0 \\
\hline
\end{tabular}

a Control containing enzyme protein, $\mathrm{CuSO}_{4}$, mercaptoethanol, potassium phospate and Tris buffer.

3. Enzymatic Synthesis of Dihydropteroic Acid from 2-Amino-4-hydroxy-(Derythro- $1^{\prime}, 2^{\prime}, 3^{\prime}$-trihydroxypropyl)dihydropteridine and Its Related Compound

The hypothetical pathway for leucopterin and xanthopterin biosynthesis from guanosine or GMP, proposed by Weygand et al. (5) consists of the following steps: (a) an opening of the imidazole ring of the guanine moiety and elimination of carbon 8 to give 4-(5'-phosphoribosyl)amino-2,5-diamino-6-hydroxypyrimidine, (b) Amadori rearrangement of the ribose residue to the corresponding $1^{\prime}$-(substitutedamino)-1'-deoxypentulose and $(c)$ cyclization of this ketose to a phosphorylated form of 2 -amino - 4-hydroxy - 6-(D-erythro-1', $2^{\prime}, 3^{\prime}$-trihydroxypropyl) dihydropteridine 
which serves as the immediate precursor of xanthopterin. Reynolds and Brown $(1,2)$ found by using $\mathrm{C}^{14}$-labelled guanosine and ribose that guanosine was incorporated except for the carbon 8 into dihydrofolic acid by the cell-free extracts of $E$. coli and the ribose moiety provides carbon atoms for the formation of the pyrazine ring. Recently, Jones, Reynolds and Brown (7) also, prepared and tested the L-threo, D-threo, and L-erythro isomers of 2-amino-4-hydroxy-6-(D-erythrotrihydroxypropyl)dihydropteridine. The D-erythro compound was the most active among the isomers tested to yield dihydropteroic acid. Shiota and Palumbo (3) also observed using Lact. plantarum the dihydrofolic acid synthesis from the Derythro, but not the L-erythro form, which had rather an inhibitory action on the production.

The present authors examined the ability of 2-amino-4-hydroxy-6-(D-erythrotrihydroxypropyl)dihydropteridine together with its isomers to be transformed into dihydropteroic acid in the plant system. The results are represented in Table 6. One can see that the D-erythro and D-threo compounds were the most active, and the L-erythro and D-threo revealed half the activity of the formers. In other experiments, a comparison of the relative activities of these isomers, as given in Table 7, showed that the D-erythro was utilized much more effectively than the other isomers. The L-threo, D-threo and L-erythro compounds gave 78, 45.4 and $31.8 \%$ of the activity of the D-erythro compound. When the D-erythro compound was used as a pteridine donor, the enzymatic formation of dihydropteroic acid was dependent on ATP, $\mathrm{Mg}^{2+}$ and $p$-aminobenzoic acid (see Table 8).

\section{TABLE 6}

Enzymatic Formation of Dihydropteroic Acid from 2-Amino-4hydroxy-6-trihydroxypropyldihydropteridine Derivatives

Reaction mixtures contained: $p$-aminobenzoic acid, $0.03 \mu$ mole; $\mathrm{MgSO}_{4} 10 \mu$ moles; mercaptoethanol, $100 \mu$ moles; potassium phosphate $(\mathrm{pH} \mathrm{8.0),} 100 \mu$ moles; dihydropteridine, $0.15 \mu$ mole; ATP, $5 \mu$ moles and enzyme protein, $10.1 \mathrm{mg}$ of Brassica pekinensis Rupr in $2 \mathrm{ml}$ of Tris- $\mathrm{HCl}, 0.1 \mathrm{M}, \mathrm{pH} 7.95$.

Incubated for $3 \mathrm{hr}$ at $30^{\circ}$ under nitrogen.

\begin{tabular}{|c|c|}
\hline $\begin{array}{l}\text { Trihydroxypropyl- } \\
\text { dihydropteridine }\end{array}$ & Folate equivalents formed \\
\hline & $m \mu g / 3 h r$ in $2 m l$ \\
\hline $\begin{array}{l}\text { 2-Amino-4-hydroxy-6-(D- } \\
\text { erythro-trihydroxypropyl)- } \\
\text { dihydropteridine }\end{array}$ & 219 \\
\hline $\begin{array}{l}\text { 2-Amino-4-hydroxy-6-(L- } \\
\text { threo-trihydroxypropyl)- } \\
\text { dihydropteridine }\end{array}$ & 216 \\
\hline $\begin{array}{l}\text { 2-Amino-4-hydroxy-6-(L- } \\
\text { erythro-trihydroxypropyl)- } \\
\text { dihydropteridine }\end{array}$ & 125 \\
\hline $\begin{array}{l}\text { 2-Amino-4-hydroxy-6-(D- } \\
\text { threo-trihydroxypropyl)- } \\
\text { dihydropteridine }\end{array}$ & 121 \\
\hline None & 0 \\
\hline $\begin{array}{l}\text { 2-Amino-4-hydroxy-6- } \\
\text { hydroxymethyldihydropteridine }{ }^{a}\end{array}$ & 221 \\
\hline
\end{tabular}

a $0.05 \mu$ mole. 
TABLE 7

Relative Activities of 2-Amino-4-hydroxy-6-trihydroxypropyldihydropteridines and 2-Amino-4-hydroxy-6-tetrahydroxybutyldihydropteridines for the Enzymatic Formation of Dihydropteroic Acid The conditons used were similar to those described in Table 6.

\begin{tabular}{|c|c|}
\hline $\begin{array}{l}\text { Polyhydroxyalkyl- } \\
\text { dihydropteridine }\end{array}$ & $\begin{array}{l}\text { Relative activity of forma- } \\
\text { tion of dihydropteroic acid }\end{array}$ \\
\hline & per cent \\
\hline $\begin{array}{l}\text { 2-Amino-4-hydroxy-6-(D-erythro- } \\
\text { trihydroxypropyl) dihydropteridine }\end{array}$ & 100 \\
\hline $\begin{array}{l}\text { 2-Amino-4-hydroxy-6-L-threo- } \\
\text { trihydroxypropyl) dihydropteridine }\end{array}$ & 78.0 \\
\hline $\begin{array}{l}\text { 2-Amino-4-hydroxy-6-(L-erythro- } \\
\text { trihydroxypropyl) dihydropteridine }\end{array}$ & 31.8 \\
\hline $\begin{array}{l}\text { 2-Amino-4-hydroxy-6-(D-threo- } \\
\text { trihydroxypropyl) dihydropteridine }\end{array}$ & 45.4 \\
\hline $\begin{array}{l}\text { 2-Amino-4-hydroxy-6-L-arabo- } 4^{\prime} \text {-deoxy- } \\
1^{\prime}, 2^{\prime}, 3^{\prime} \text {-trihydroxybutyl) dihydropteridine }\end{array}$ & 117.5 \\
\hline $\begin{array}{l}\text { 2-Amino-4-hydroxy-6-(D-arabo-1 } 1^{\prime}, 2^{\prime}, 3^{\prime}, 4^{\prime} \text { - } \\
\text { tetrahydroxybutyl) dihydropteridine }\end{array}$ & 69.7 \\
\hline $\begin{array}{l}\text { 2-Amino-4-hydioxy-6-(D-lyxo-1' }, 2^{\prime}, 3^{\prime}, 4^{\prime} \text { - } \\
\text { tetrahydroxybutyl) dihydropteridine }\end{array}$ & 30.6 \\
\hline
\end{tabular}

\section{TABLE 8}

Enzymatic Formation of Dihydropteroic Acid from 2-Amino-4hydroxy-6-(D-erythro-trihydroxypropyl) dihydropteridine

Reaction mixtures contained: $p$-aminobenzoic acid, $0.03 \mu$ mole; $\mathrm{MgSO}_{4}, 10 \mu$ moles ; potassium phosphate ( $\mathrm{pH} 8.0), 100 \mu$ moles; mercaptoethanol, $100 \mu$ moles; dihydropteridine, $0.15 \mu$ mole; ATP, $5 \mu$ moles and enzyme protein, $10.2 \mathrm{mg}$ of Brassica pekinensis $\mathrm{Rupr}$ in $2 \mathrm{ml}$ of Tris- $\mathrm{HCl}$ buffer, $0.1 \mathrm{M}$, pH 7.95 .

Incubated for $3 \mathrm{hr}$ at $30^{\circ}$ under nitrogen.

\begin{tabular}{lc}
\hline \multicolumn{1}{c}{ Reaction mixture } & Folate equivalents formed \\
& $m \mu g / 3 \mathrm{hr}$ in $2 \mathrm{ml}$ \\
Complete & 208 \\
Omit MgSO $_{4}$ & 0 \\
Omit pteridine $a$ & 0 \\
Omit p-aminobenzoic acid & 95 \\
Omit enzyme & 0 \\
Omit ATP & 0 \\
2-Amino-4-hydroxy-6- & 188 \\
hydroxymethyldihydropteridine & \\
used (0.05 $\mu$ mole) & \\
a 2-Amino-4-hydroxy-6-(D-erthro-trihydroxypropyl)dihydropteridine.
\end{tabular}

These findings allowed the present authors to attempt to prepare 6-butyldihydropteridine derivatives and to test the possibility of these substances to be utilized as the substrates in the enzymatic reaction to form dihydropteroic acid. As shown in Table 7, 2-amino-4-hydroxy-6-(L-arabo-1',2',3'-trihydroxy-4'-deoxybutyl)dihydropteridine was equally as active as the D-erythro-trihydroxypropyldihydropteridine. 2 - Amino - 4 - hydroxy - 6 - (D-arabo-1', $2^{\prime}, 3^{\prime}, 4^{\prime}$-tetrahydroxybutyl) dihydropteridine and 2-amino-4-hydroxy-6-(D-lyxo-1', $2^{\prime}, 3^{\prime}, 4^{\prime}$-tetrahydroxybutyl) dihydropteridine 
gave the activities of 69.7 and $30.6 \%$, respectively, against the D-erythro compound. In the present investigation we can not give any answer for what means the enzyme reacts with polyhydroxyalkylpteridine in the metabolism of pteridine compounds in plants. However, it should be noted that the analogue of these substances does indeed exist in nature as active compounds. Occurence of 2 -amino4-hydroxy-6-trihydroxypropylpteridine as a natural product was demonstrated firstly by Goto and Forrest (21), who isolated the phosphate ester of this pteridine from E. coli. 2-Amino-4-hydroxy-6-(D-erythro-trihydroxypropyl) pteridine was isolated from the pupae of the bee and hoey, and characterized by Rembold and Buschman (6). The other isomers of this pteridine have not been found. Recently, Sakurai and Goto (22) isolated 2-amino-4-hydroxy-6-tetrahydroxybutylpteridine from human urine, and, also, Goto et al. (23) obtained 2 - $\beta$-glucuronide of 2 -amino-4-hydroxy-6$1^{\prime}, 2^{\prime}, 3^{\prime}, 4^{\prime}, 5^{\prime}$-pentahydroxypentylpteridine from Mycobacterium smegmatis, which had the activity for Crithidia fasciculata as a growth factor.

4. No Requirements of $\mathrm{Mg}^{2^{+}}$and ATP for Enzymatic Conversion of 2-Amino4-hydroxy-6-(D-erythro-1',2',3'-trihydroxypropyl)dihydropteridine to 2-Amino-4hydroxy-6-hydroxymethyldihydropteridine

Recently, using $\mathrm{C}^{14}$-labelled compound, the reduced form of 2-amino-4-hydroxy6-trihydroxypropylpteridine was proved in Drosophila melanogaster to be incorporated into 2-amino-4-hydroxy-6-methylpteridine, which was supposed to be derived from 2-amino-4-hydroxy-6-hydroxymethyldihydropteridine (26).

As demonstrated in previous communications $(8,9)$, ATP and $\mathrm{Mg}^{2+}$ were required for coupling of 2 -amino-4-hydroxy-6-hydroxymethyldihydropteridine with $p$-aminobenzoic acid to produce dihydropteroic acid. In order to confirm whether ATP and $\mathrm{Mg}^{2+}$ are involved or not in the enzymatic conversion of 2-amino-4hydroxy-6-(D-erythro-trihydroxypropyl) dihydropteridine to 2-amino-4-hydroxy-6-hydroxymethyldihydropteridine, experiments were carried out as follows. In preincubation at $30^{\circ}$ for one hour under nitrogen two different reaction mixtures, the trihydroxypropyldihydropteridine with the enzyme, and the same pteridine and $\mathrm{Mg}^{2+}$ with the enzyme, were incubated. At the end of the period, to the former reaction system was added $p$-aminobenzoic acid, ATP and $\mathrm{Mg}^{2+}$, and to the latter, ATP and $p$-aminobenzoic acid. The two reaction media were reincubated at $30^{\circ}$ under nitrogen in parallel with the control not preincubated system, and the formation of dihydropteroic acid was followed in the course of time. From the data shown in Fig. 1, one can observe that, in the reaction mixture containing trihydroxypropyldihydropteridine with the enzyme preincubated before addition of ATP, $p$-aminobenzoic acid and $\mathrm{Mg}^{2+}$, dihydropteroic acid was produced with a yield higher than in the medium without preincubation. These observations suggested the possibility that the conversion of trihydroxypropyldihydropteridine to hydroxymethyl. dihydropteridine might procced without ATP and $\mathrm{Mg}^{2^{+}}$during the preincubation period.

5. No Effectiveness of 2-Amino-4-hydroxydihydropteridine as a Donor for Enzymatic Synthesis of Dihydropteroic Acid

Forrest and Nawa (25) proposed that a three-carbon unit of the side chain of reduced 2-amino-4-hydroxy-6-(D-erythro-trihydroxypropyl)pteridine is cleaved to 


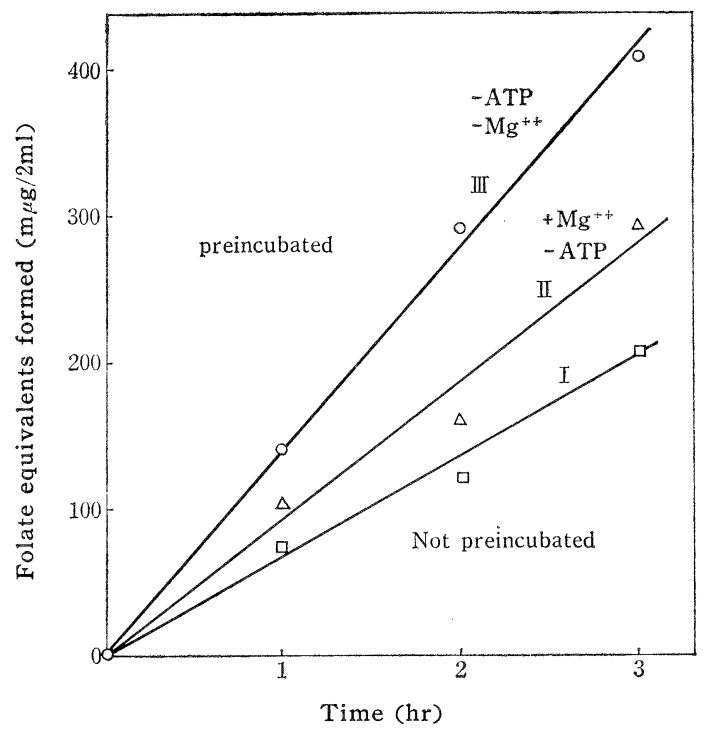

FIG. 1 Effect of Preincubation of Enzyme and 2-Amino-4-hydroxy-6(D-erythro-trihydroxypropyl)dihydropteridine in the Presence and the Absence of $\mathrm{Mg}^{++}$on the Formation of Dihydropteroate

Reaction mixtures contained: $p$-aminobenzoic acid, $0.03 \mu$ mole; $\mathrm{MgSO}_{4}$, $10 \mu$ moles; mercaptoethanol, $100 \mu$ moles; potassium phosphate, ( $\mathrm{pH} 8.0$ ), $100 \mu$ moles ; 2-amino-4-hydroxy-6-(D-erythro-trihydroxypropyl)dihydropteridine, $0.15 \mu$ mole; ATP, $5 \mu$ moles; and enzyme protein, $11.3 \mathrm{mg}$ of Brassica pekinensis $R$ upr for one hour at $30^{\circ}$ under nitrogen. Reaction proceeded for $3 \mathrm{hr}$ at $30^{\circ}$ under nitrogen.

I, no preincubation; II, preincubation in the presence of magnesium ion and the absence of ATP; III, preincubation in the absence of both ATP and magnesium ion.

form reduced 2-amino-4-hydroxypteridine, which is then converted to reduced 2amino-4-hydroxy-6-hydroxymethylpteridine by addition of a one-carbon unit and sepiapterin by addition of a three-carbon unit. Okada and Goto (24) found that the reduced form of 2-amino-4-hydroxypteridine-10-C ${ }^{14}$ was incorporated into isoxanthopterin and sepiapterin in Drosophila melanogaster.

The present authors examined the possibility that 2-amino-4-hydroxydihydropteridine functions as an intermediate in the enzymatic formation of dihydropteroic acid. As presented in Table 9, this pteridine failed to reveal any effects in the plant system.

Baugh and Shaw (27) have reported that the intact cells of Corynebacterium species can incorporate radioactivity from 2,4,5-triamino-6-hydroxypyrimidine-5-C ${ }^{14}$ into pteridine compounds. This possibility of the formation of dihydropteroic acid in the plant system could be excluded from the finding that under the conditions employed in Table 1 in which this pyrimidine and ribose instead of guanosine compounds were incubated with the enzyme, any compound active for St. faecalis $R$ was failed to be detected. 
TABLE 9

No Effectiveness of 2-Amino-4-hydroxydihydropteridine as Precursor for Enzymatic Synthesis of Dihydropteroic Acid

Reaction mixtures contained: $p$-aminobenzoic acid, $0.03 \mu$ mole; $\mathrm{MgSO}_{4}, 10 \mu$ moles; mercaptoethanol, $100 \mu$ moles; potassium phosphate ( $\mathrm{pH} 8.0$ ), $100 \mu$ moles; dihydropteridine, $0.15 \mu$ mole ; carbon donor, $0.15 \mu$ mole; ATP, $5 \mu$ moles and enzyme protein, $8.4 \mathrm{mg}$ of Brassica pekinensis Rupr in $2 \mathrm{ml}$ of Tris- $\mathrm{HCl}, 0.1 \mathrm{M}, \mathrm{pH} 7.95$.

Incubated for $3 \mathrm{hr}$ at $30^{\circ}$ under nitrogen.

\begin{tabular}{lc}
\hline Reaction mixtures & $\begin{array}{c}\text { Folate equivalents formed } \\
\text { in 2 ml }\end{array}$ \\
\hline & $m \mu g / 3 \mathrm{hr}$ \\
2-Amino-4-hydroxydihydropteridine only & 0 \\
Plus DL-glyceraldehyde & 0 \\
Plus 3-phospho-D-glycerate & 0 \\
Plus DL- $\alpha$-glycerolphosphate & 0 \\
Plus sodium pyruvate & 0 \\
Plus glyoxylic acid & 0 \\
Plus acetic acid & 0 \\
Plus ethanol & 0 \\
Plus formic acid & 0 \\
Plus formaldehyde & 0 \\
Plus D-ribose & 0 \\
Plus D-arabinose & 0 \\
Plus L-arabinose & 0 \\
Plus D-xylose & 0 \\
Plus L-xylose & 0 \\
2-Amino-4-hydroxy-6-(D-erythro- & 150 \\
trihydroxypropyl) dihydropteridine & \\
2-Amino-4-hydroxy-6-hydroxymethyl- & 150 \\
dihydropteridine &
\end{tabular}

a $0.05 \mu$ mole

TABLE 10

Enzymatic Formation of Dihydropteroic Acid from 2-Amino-4hydroxy-6-hydroxymethyldihydropteridine Pyrophosphate and p-Aminobenzoic Acid

Reaction mixtures contained: $p$-aminobenzoic acid, $0.03 \mu$ mole; $\mathrm{MgSO}_{4} 10 \mu$ moles; potassium phosphate $(\mathrm{pH} 8.0), 100 \mu$ moles; mercaptoethanol, $100 \mu$ mole; dihydropteridine, $0.05 \mu$ mole and enzyme protein, $12.5 \mathrm{mg}$, of Brassica pekinensis Rupr in $2 \mathrm{ml}$ Tris- $\mathrm{HCl}$ buffer, $0.1 \mathrm{M}, \mathrm{pH} 7.95$.

Incubated for $3 \mathrm{hr}$ at $30^{\circ}$ under nitrogen. Reaction was stopped by addition of $0.1 \mathrm{ml}$ of mercaptoethanol. Dihydropteroic acid was determined by microbiological assay with $S$. faecalis $R$.

\begin{tabular}{lc}
\hline \multicolumn{1}{c}{ Reaction mixture } & $\begin{array}{c}\text { Folate equivalents formed } \\
\text { in } 2 \mathrm{ml}\end{array}$ \\
& $m \mu g / 3 \mathrm{hr}$ \\
Complete & 217 \\
Omit MgSO $_{4}$ & 0 \\
Omit pteridine & 0 \\
Omit py-aminobenzoic acid & 59 \\
Omit enzyme & 0 \\
Pteridine ${ }^{a}$-monophosphate used & 0 \\
Pteridine used & 0 \\
Pteridine $^{a}$ plus ATP (5 4 moles) & 158 \\
\hline
\end{tabular}

a 2-Amino-4-hydroxy-6-hydroxymethyldihydropteridine. 
6. Enzymatic Synthesis of Dihydropteroic Acid from 2-Amino-4-hydroxy-6hydroxymethyldihydropteridine Pyrophosphate

The enzymatic synthesis of dihydropteroic acid from 2-amino-4-hydroxy-6hydroxymethyldihydropteridine and p-aminobenzoic acid by the cell-free extracts of spinach leaves had been shown to require ATP and $\mathrm{Mg}^{2+}(8,9)$, postulating that a pyrophosphate ester of this pteridine might be involved in the formation of dihydropteroic acid. Recently, Iwai et al. (10) prepared the pyrophosphate ester according to the method of Shiota et al. (14) and found that the ester could combine with $p$-aminobenzoic acid to yield dihydropteroic acid by the extracts of soy bean seedlings in the absence of ATP. The same evidence was presented by the present authors with the enzyme preparation of Brassica pekinensis Rupr as given in Table 10. The pyrophosphate ester could be converted into dihydropteroic acid only in the presence of $\mathrm{Mg}^{2+}$, but the monophosphate ester was not utilized.

These observations in higher plants are quite in agreement with those of Shiota et al. $(14,28)$ with Lact. plantarum, who demonstrated firstly these evidences, and also with that made by Weiman and Brown in E. coli system (29).

\section{SUMMARY}

1. Cell-free extracts of Brassica pekinensis Rupr (Hakusai) catalyzed the formation of dihydropteroic acid from guanosine compounds and $p$-aminobenzoic acid. This reaction required $\mathrm{ATP}, \mathrm{Mg}^{2+}$ and phosphate.

2. GTP and GDP were more active in dihydropteroic acid synthesis than GMP and guanosine. When GTP was used as substrate, the synthesis was absolutely dependent on ATP and $\mathrm{Mg}^{2+}$.

3. 2-Amino-4-hydroxy-6-(D-erythro- $1^{\prime}, 2^{\prime}, 3^{\prime}$ - trihydroxypropyl) dihydropteridine was the most active as a pteridine donor for the formation of dihydropteroic acid. This enzyme reaction needed ATP and $\mathrm{Mg}^{2+}$. The L-erythro, D-threo and L-threo isomers of 2 -amino-4-hydroxy-6-(D-erythro-trihydroxypropyl) dihydropteridine, 2 amino - 4- hydroxy - 6-(L-arabo-1', $2^{\prime}, 3^{\prime}$ - trihydroxy - 4' - deoxybutyl) dihydropteridine, 2 amino - 4-hydroxy - 6 - (D-arabo-1 $, 2^{\prime}, 3^{\prime}, 4^{\prime}$ - tetrahydroxybutyl) dihydropteridine and 2 amino-4-hydroxy-6-(D-lyxo-1', $2^{\prime}, 3^{\prime}, 4^{\prime}$-tetrahydroxybutyl) dihydropteridine were tested in the ability of enzymatic transformation to dihydropteroic acid.

4. 2-Amino - 4- hydroxy - 6 - (D - erythro - $1^{\prime}, 2^{\prime}, 3^{\prime}$ - trihydroxypropyl) dihydropteridine seemed to convert to 2-amino-4-hydroxy-6-hydroxymethyldihydropteridine without $\mathrm{ATP}$ and $\mathrm{Mg}^{2+}$.

5. 2-Amino-4-hydroxydihydropteridine and 2,4,5-triamino-6-hydroxypyrimidine were not involved in the synthesis of dihydropteroic acid.

6. 2-Amino-4-hydroxy-6-hydroxymethyldihydropteridine pyrophosphate could be converted into dihydropteroic acid only in the presence of $\mathrm{Mg}^{2+}$. The monophosphate ester was not utilized in the conversion.

\section{ACKNOWLEDGEMENT}

We are deeply indebted to Prof. T. Mitsui, Faculty of Agricultural Chemistry, Department of Agriculture, Kyoto University, for his kindness for ultimate analysis of synthetic compounds, 
and also would acknowledge the kind criticism of Prof. K. Iwai, Institute for Food Science, Kyoto University. We are grateful to Mr. M. Shimada for his cooperation with us in a part of these investigations.

\section{REFERENCES}

1. Reynolds, J.J., and Brown, G. M., J. Biol. Chem. 239, 317 (1964).

2. Reynolds, J. J., and Brown, G. M., J. Biol. Chem. 237, PC2713 (1962).

3. Shiota, T., and Palumbo, M. P., J. Biol. Chem., 240, 4449 (1965).

4. Dalal, R., and Gots, J. S., Biochem. Biophys. Research Comm., 20, 509 (1965).

5. Weygand, F., Simon, H., Dahms, G., Waldshmidt, M., Schliep, H. J., and Wacker, H., Angew. Chem., 73, 402 (1961).

6. Rembold, H., and Buschmann, L., Chem. Ber., 96, 1406 (1963).

7. Jones, T. H.D., Reynolds, J. J., and Brown, G. M., Biochem. Biophys Research Comm., 17, 486 (1964).

8. Mitsuda, H., Kawai, F., and Suzuki, Y., Vitamins 28, 453 (1963).

9. Mitsuda, H., Suzuki, Y., Tadera, K., and Kawai, F., J. Vitaminol., 11, 122 (1965).

10. Iwai, K., Okinaka, O., and Suzuki, N., Seikagaku 36, 644 (1964).

11. Mitsuda, H., Suzuki, Y., Tadera, K., Shimada, M., and Kawai, F., Seikagaku 37, 602 (1965).

12. Forrest, H. S., and Walker, J., J. Chem. Soc., 2077 (1949).

13. Waller, C. W., Goldman, A. A., Angier, R. B., Boothe, J. H., Huchings, B. L., Mowat, J. H., and Semb, J., J. Amer. Chem. Soc. 72, 4630 (1950).

14. Shiota, T., Disraely, M. N., and McCann, M.P., Biochem. Biophys. Research. Comm., 7, 194 (1962).

15. Traube, W., Chem. Ber., 33, 1371 (1900).

16. Mowat, J. H., Boothe, J.H., Hutchings, B. L., Stokstad, E. L. R., Waller, C. W., Angier, R. B., Semb, J., Cosulich, D. B., and SubbaRow, Y., J. Amer. Chem. Soc., 70, 14 (1948).

17. Waller, C. W., Huchings, B. L., Mowat, J. H., Stokstad, E. L. R., Boothe, J. H., Anginer, R. B., Subbarow, Y., Cosulich, D.B., Fahrenbach, M. J., Hultouist, M.E., Kuh, E., Northey, E. H., Seeger, D. R., Sickels, J. P., and Smith, J. M. Jr., J. Amer. Chem. Soc., 70, 19 (1948).

18. Weygand, F., Wacker, A., and Schied-Kowarzick, V., Chem. Ber., 82, 25 (1949).

19. Futterman, S., J. Biol. Chem., 228, 1031 (1957).

20. Kalcker, H. M., J. Biol. Chem., 167, 461 (1947).

21. Goto, M., and Forrest, H. S., Biochem. Biophys. Research Comm., 6, 180 (1961).

22. Sakurai, A., and Goto, M., the 18th Annual Meeting of the Chemical Society of Japan, April, 1965.

23. Goto, M., Kobayashi, K., Sato, H., and Korte, F., Ann. Chem. 689, 221 (1965).

24. Okada, T., and Goto, M., J. Biochem., 58, 458 (1965).

25. Forrest, H. S., and Nawa, S., Pteridine Chemistry, ed. by W. Pfleiderer and E. C. Taylor, Pergamon Pres Inc., New York, p. 281 (1964).

26. Goto, M., Okada, T., and Forrest, H. S., Arch Biochem. Biophys. 110, 409 (1965).

27. Baugh, C. H., and Shaw, E., Biochem. Biophys Research Comm., 10, 28 (1963).

28. Shiota, T., Disraely, M. N., and McCann, M.P., J. Biol. Chem. 239, 2259 (1964).

29. Weisman, R. A., and Brown, G. M., J. Biol. Chem. 239, 326 (1964). 